Article

\title{
Ecotoxicological Effect of Single and Combined Exposure of Carbamazepine and Cadmium on Female Danio rerio: A Multibiomarker Study
}

\author{
Chunhong Shi ${ }^{1}$, Yide $\mathrm{He}^{2,3, *(\mathbb{D})}$, Jiaxin Liu ${ }^{2}$, Yue $\mathrm{Lu}^{2}$, Yuting Fan ${ }^{2}$, Yaling Liang ${ }^{2}$ and \\ Yanhua $\mathrm{Xu}^{2, *}$ \\ 1 School of Energy and Environmental Engineering, University of Science and Technology Beijing, Beijing Key \\ Laboratory of Resource-Oriented Treatment of Industrial Pollutants, Beijing 100083, China; sch.22@163.com \\ 2 School of Environmental Science and Engineering, Nanjing Tech University, Nanjing 211816, China; \\ 422751557@njtech.edu.cn (J.L.); 327430834@njtech.edu.cn (Y.L.); 1689452692@njtech.edu.cn (Y.F.); \\ 434831792@njtech.edu.cn (Y.L.) \\ 3 Nanjing Chemical Industry Park Environmental Protection Industry Collaborative Innovation Center, Luhe, \\ Nanjing 211500, China \\ * Correspondence: heyd@njtech.edu.cn (Y.H.); yanhuaxu18@hotmail.com (Y.X.); Tel.: +86-25-58139656
}

Received: 30 January 2019; Accepted: 25 March 2019; Published: 31 March 2019

check for updates

\begin{abstract}
In aquatic environments, organisms are exposed to mixtures of pollutants which may change the toxicity profile of each contaminant, compared to its toxicity alone. Carbamazepine (CBZ) and cadmium $(\mathrm{Cd})$ are among the pollutants that co-occur in aquatic environments. To date, most research about their toxicity towards aquatic vertebrates is based on single exposure experiments. The present study aims to evaluate single and combined effects of CBZ and Cd on biomarkers in female Danio rerio (zebrafish) by exposing them to environmentally relevant concentrations of these two pollutants for ten days. Four kinds of biomarkers involved in antioxidant systems, energy metabolism, nervous system, and endocrine disruption, respectively, were studied. Our research results coincided with those of former studies in single exposure experiments. However, the combined exposure of CBZ and Cd exerted different responses from other studies in which these two contaminants were examined alone in zebrafish. The present study evidenced the need to conduct more coexposure studies to enhance the environmental relevance of these experimental results.
\end{abstract}

Keywords: carbamazepine; cadmium; combined toxicity; biomarkers

\section{Introduction}

Pharmaceuticals and personal care products (PPCPs) are widely used in daily life throughout the world [1], which lead to their frequent detection in different environments [2-4]. Hence, PPCPs have been recognized as emerging pollutants, whose potential adverse effects on nontarget organisms have drawn more and more attention $[5,6]$.

Carbamazepine (CBZ) has been widely used in the treatment of epilepsy, psychomotor attacks, and trigeminal neuralgia effects [7]. Its annual consumption consists of over 1000 tons [8]. Approximately $30 \%$ of oral CBZ dosage is excreted in urine and feces in its unaltered form [8]. In addition, the conventional treatment process in wastewater treatment plants (WWTPs) was found to be invalid for its removal $[9,10]$. Its continuous discharge and long half-life in water leads to its frequent detection in aquatic systems [11]. The concentration of CBZ in aquatic systems was reported to range from 0.03 to $11.6 \mu \mathrm{g} / \mathrm{L}$ throughout the world [12-15]. 
Previous studies showed that CBZ could have adverse effects on the health of aquatic organisms. Oxidative stress has been reported as an important impact of CBZ on aquatic organisms [16-18]. Besides, CBZ was also found to cause delay in the first reproduction age in Daphnia magna [19], behavioral modification in Dugesia tigrina [20], and even endocrine-disrupting effects on Gobiocypris rarus [21].

However, most research concerning CBZ toxicity to aquatic organisms has focused on its individual effects. Regarding zebrafish, a very limited number of articles describes the combined effect of CBZ with other pollutants. In fact, organisms are exposed to complex mixtures of pollutants that may interact and exert effects quite different from single-compound exposure [22]. The interactions of multiple stressors and related biochemical responses of exposed organisms may be completely different from the mode of action (MoA) of each single pollutant [23].

PPCPs and metals frequently co-occur in aquatic environments [24-26]. Among these metals, cadmium (Cd) is on the list of priority substances Annex I of the Directive 2013/39/EU. Cd is widely applied in industry, which leads to its rapid release into aquatic systems; this has aroused wide public concerns in recent years [27]. Archary et al. reported that Cd was detected in coastal waters of Kalpakkam on southeast coast of India, with a concentration of $1.6 \pm 0.15 \mu \mathrm{g} / \mathrm{L}$ [28]. Jitar et al. mentioned in their paper that the concentration of $\mathrm{Cd}$ in water samples of the Romanian coastline of the Black Sea was 0.41 50 $\mu \mathrm{g} / \mathrm{L}$ [29]. Yiğiterhan et al. reported that the concentration of Cd in sea water ranged from 1.5 to $3.65 \mathrm{ng} / \mathrm{L}$ [30]. The adverse effects of single exposure to Cd are a well-known issue [31-33]. However, few studies can be found which investigate the impacts induced by the combination of Cd with PPCPs [34-36].

Despite the available toxicity data for Cd and CBZ [37], to our best knowledge, no research has evaluated their combined adverse effects on zebrafish. In the present study, we aimed to evaluate the single and combined effects of these two pollutants on several biomarkers involved in different biochemical process, such as antioxidant systems, energy metabolism, nervous system, and reproduction/endocrine disruption in zebrafish, by exposing female zebrafish to environmentally relevant concentrations for ten days.

\section{Materials and Methods}

\subsection{Chemicals}

Carbamazepine (CBZXilong, Guangzhou, China), $\mathrm{CdCl}_{2} \cdot 5 / 2 \mathrm{H}_{2} \mathrm{O}$ (Xilong, Guangzhou, China), $\mathrm{NaCl}$ (Xilong, Guangzhou, China), $\mathrm{CaCl}_{2} \cdot 2 \mathrm{H}_{2} \mathrm{O}$ (Sinopharm, Shanghai, China), $\mathrm{MgSO}_{4} \cdot 7 \mathrm{H}_{2} \mathrm{O}$ (Lingfeng, Shanghai, China), $\mathrm{NaHCO}_{3}$ (Lingfeng, Shanghai, China), $\mathrm{KCl}$ (Lingfeng, Shanghai, China). The catalase (CAT) kit (KeyGEN, Nanjing, China), the lactate dehydrogenase (LDH) kit (KeyGEN, Nanjing, China), and the Bradford protein quantitation assay kit (KeyGEN, Nanjing, China), Acetylcholinesterase (AChE) kit (Jiancheng, Nanjing, China), the superoxide dismutase (SOD) kit (Jiancheng, Nanjing, China) The vitellogenin (VTG) kit (Enzyme-linked Biotechnology, Shanghai, China), the estradiol (E2) kit (Enzyme-linked Biotechnology, Shanghai, China) were purchased before experiment.

\subsection{Zebrafish Husbandry}

Mature wild-type female zebrafish (Tübingen line, YSY, Nanjing, China ) were purchased and maintained in the laboratory for a month before exposure. Every tenth zebrafish was placed in a $3 \mathrm{~L}$ tank containing a $2 \mathrm{~L}$ culture medium $(0.6 \mathrm{~g} / \mathrm{L} \mathrm{NaCl})$. During this period, they were maintained at $28 \pm 0.5^{\circ} \mathrm{C}$ with a $14 / 10 \mathrm{~h}$ light and dark cycle and fed three times daily with live baby brine shrimp for five minutes. Then, $75 \%$ of the culture medium was renewed after feeding. 


\subsection{Exposure Protocol}

After acclimation, a total of 140 zebrafish were submitted to ten-day exposure. Every tenth zebrafish was randomly placed in a $3 \mathrm{~L}$ tank containing a $2 \mathrm{~L}$ chemical exposure solution, evaluating their responses to seven treatments with two replicates for each group on separate occasions: control

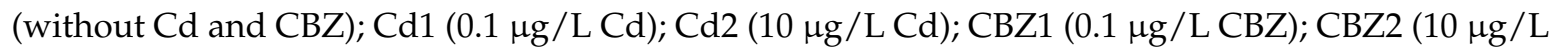

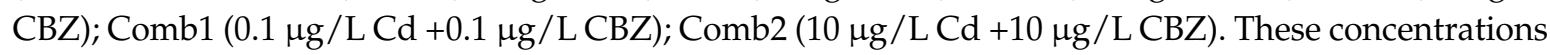
were chosen according to realistic environmental concentrations. After feeing, $75 \%$ of the exposure medium was renewed. Feeding was stopped $24 \mathrm{~h}$ before the harvest. After exposure, zebrafish were killed on ice and stored at $-80^{\circ} \mathrm{C}$ for further study.

\subsection{Biomarkers}

The homogenized sample (the whole fish) in $0.6 \% \mathrm{NaCl}$, using a hand-held cell crusher (MS FastPrep-1, SantaAna, California, America), was centrifuged at $8500 \mathrm{rpm}$ for $10 \mathrm{~min}$ at $4{ }^{\circ} \mathrm{C}$. The supernatant was collected. Measurement of biomarkers are briefly described as follows:

\subsubsection{Antioxidant Enzymes}

The enzyme activity was assessed following the instructions provided by the commercial kits. One SOD activity unit was expressed as the amount of enzyme corresponding to the SOD inhibition rate of $50 \%$ in the reaction system. The activities of CAT were expressed as the number of micromolar $\mathrm{H}_{2} \mathrm{O}_{2}$ consumed per minute per milligram of protein.

\subsubsection{Biomarker Concerning Energy Metabolism}

The LDH activity was determined following the instruction provided by the commercial kit. One LDH activity unit was defined as $1 \mathrm{mmol}$ pyruvic acid being produced in the reaction system after $1 \mathrm{~g}$ of tissue protein reacted with the substrate at $37^{\circ} \mathrm{C}$ for $15 \mathrm{~min}$.

\subsubsection{Biomarker in the Nervous System}

AChE hydrolyzes acetylcholine to produce choline and acetic acid. The amount of choline hydrolyzed can be reflected by the activity of AChE. AChE activity was indirectly assessed using choline content that was quantitatively determined by colorimetric determination following the instructions from the commercial kit.

\subsubsection{Biomarkers Reflecting Reproduction/Endocrine Disruption:}

E2 and VTG concentration were tested by using commercial enzyme-linked immunosorbent assay (ELISA) commercial kits. The absorbance (OD value) was measured at a wavelength of $450 \mathrm{~nm}$ using a microplate reader to calculate the sample concentration.

\subsection{Statistical Analyses}

All data were analyzed with PASW Statistics 18, including the focus on one-way ANOVA for all kinds of biomarkers. The value $p<0.05$ indicates that the difference was significant at a 0.05 level, indicated by "**"; $p<0.01$ indicates that the difference was significant at 0.01 level, indicated by "**"; $p<0.001$ indicates that the difference was significant at the 0.001 level, indicated by "***". All the graphics were generated with the help of Origin 8.0.

\section{Results}

\subsection{Mortality}

After ten days of exposure, none of the tested conditions induced mortality. 


\subsection{Antioxidant Enzymes}

The SOD activity, depicted in Figure 1A, increased sharply compared to the control group when exposed to $0.1 \mu \mathrm{g} / \mathrm{L} \mathrm{Cd}$, and continued to increase when exposed to $10 \mu \mathrm{g} / \mathrm{L} \mathrm{Cd}$. When exposed to CBZ, the SOD activity in female zebrafish increased slightly in comparison with the control group. When exposed to the combination of Cd and CBZ, the SOD activity increased sharply in the $0.1 \mu \mathrm{g} / \mathrm{L}$ $\mathrm{Cd}+0.1 \mu \mathrm{g} / \mathrm{L} \mathrm{CBZ}$ group, even higher than in the $0.1 \mu \mathrm{g} / \mathrm{L}$ Cd group, and the increasing combination concentration did not lead to the continual increase of SOD activity. As shown in Figure 1B, CAT activity was reduced by $\mathrm{Cd}$ exposure and was suppressed in the CBZ exposure group at low concentration, but was induced in this group at a high CBZ concentration. The data from the combined treatments suggested that the combined exposure of $\mathrm{Cd}$ and $\mathrm{CBZ}$ exerted less effects on CAT activity compared to single Cd exposure.

A

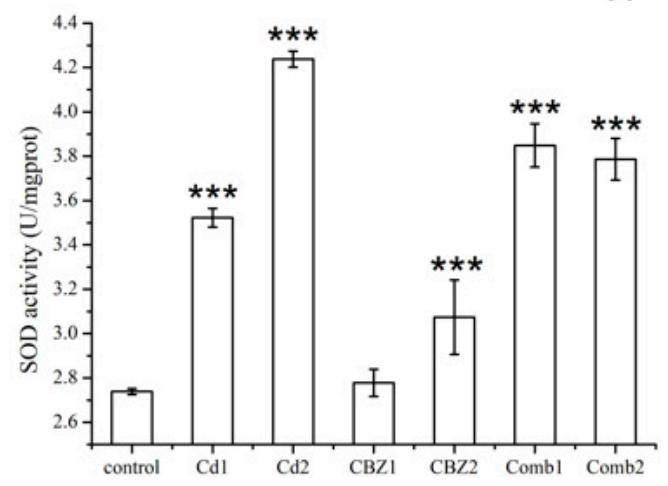

B

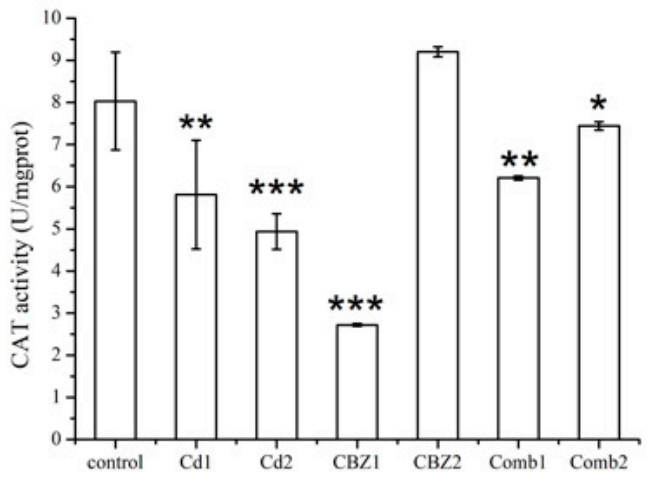

Figure 1. (A) Superoxide dismutase (SOD) activities and (B) the catalase (CAT) activities in female zebrafish after ten days of exposure to cadmium (Cd), carbamazepine (CBZ), and Cd $+\mathrm{CBZ}$. The results of one-way ANOVA are indicated at the significance levels ${ }^{*} p<0.05,{ }^{* *} p<0.01$, and ${ }^{* * *} p<0.001$.

\subsection{Biomarker in the Nervous System}

The AChE activity is depicted in Figure 2, showing that its activity decreased in all single exposure groups, and was induced in the combined exposure groups.

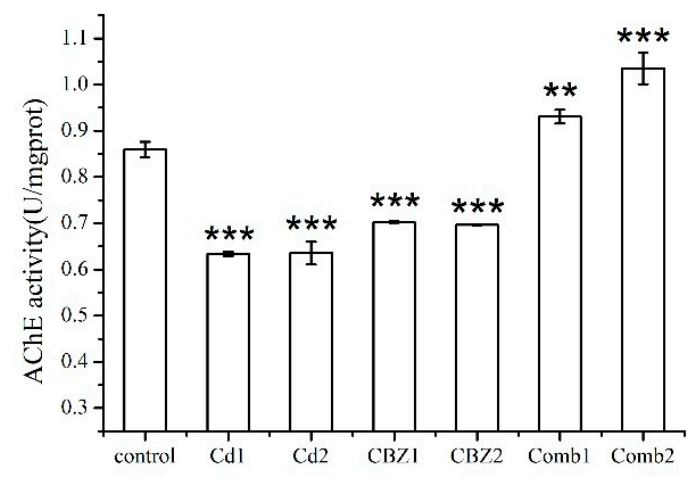

Figure 2. Acetylcholinesterase (AChE) activity in female fish after ten days of exposure to $\mathrm{Cd}, \mathrm{CBZ}$, and $\mathrm{Cd}+\mathrm{CBZ}$. The results of one-way ANOVA are indicated at the significance levels ${ }^{*} p<0.05,{ }^{* *} p<0.01$, and ${ }^{* * *} p<0.001$.

\subsection{Biomarker Concerning Energy Metabolism}

The LDH activity is depicted in Figure 3, and was suppressed by Cd exposure. 


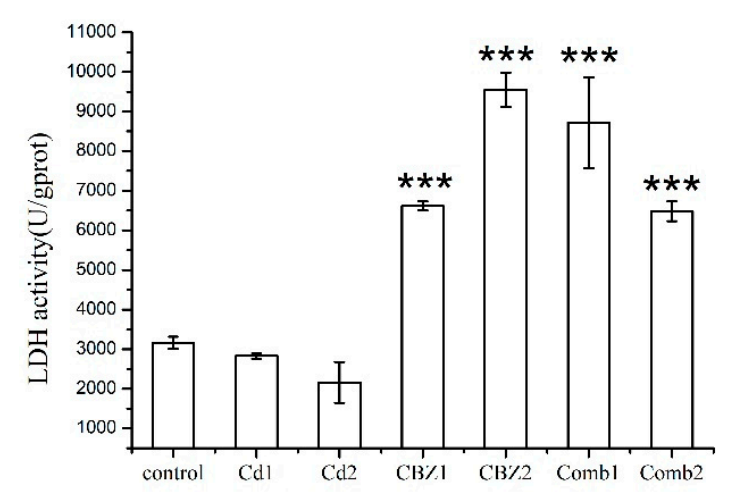

Figure 3. Lactate dehydrogenase (LDH) activity in female fish after ten days of exposure to Cd, CBZ, and $\mathrm{Cd}+\mathrm{CBZ}$. The results of one-way ANOVA are indicated at the significance levels ${ }^{*} p<0.05$, ** $p<0.01$, and ${ }^{* * *} p<0.001$.

\subsection{Biomarkers Reflecting Reproduction/Endocrine Disruption}

As shown in the Figure 4, VTG content and E2 decreased sharply in Cd exposure groups, and both showed similar tendencies.

A

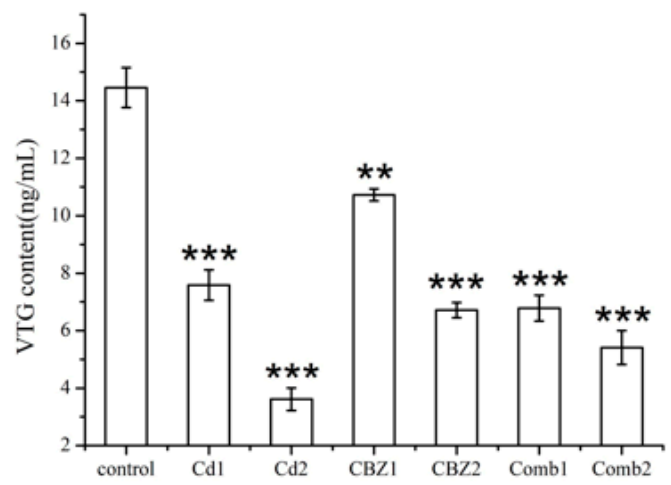

B

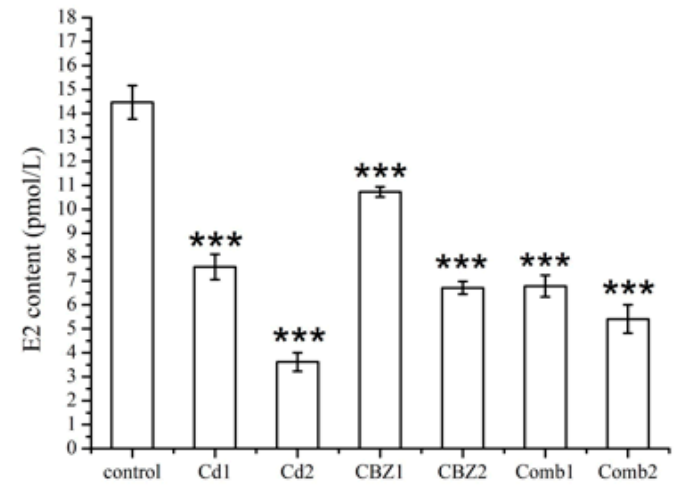

Figure 4. (A) Vitellogenin (VTG) content and (B) Estradiol (E2) content in female fish after ten -days of exposure to $\mathrm{Cd}, \mathrm{CBZ}$, and $\mathrm{Cd}+\mathrm{CBZ}$. The results of one-way ANOVA are indicated at the significance levels ${ }^{*} p<0.05,{ }^{* *} p<0.01$, and ${ }^{* * *} p<0.001$.

\section{Discussion}

Cd was found to induce reactive oxygen species (ROS) production and oxidative stress in zebrafish at a nonlethal concentration, which can enhance SOD activity to eliminate the ROS radicals [38]. When exposed to CBZ, the SOD activity in female zebrafish increased slightly in comparison with the control group. Similar trends of SOD activity displayed in previous studies neutralized the impact of increased ROS generation in rainbow trout after chronic CBZ treatment [39]. When exposed to the combination of Cd and CBZ, the SOD activity increased sharply in the $0.1 \mu \mathrm{g} / \mathrm{L} \mathrm{Cd}+0.1 \mu \mathrm{g} / \mathrm{L}$ CBZ group, even higher than in the $0.1 \mu \mathrm{g} / \mathrm{L}$ Cd group. Interestingly, the increasing combination concentration did not lead to the continual increase of SOD activity. Almeida et al. studied the effects of single and combined exposure of CBZ and Cd of R. philippinarum, and found that SOD activity increased when exposed to the $0.5 \mu \mathrm{g} / \mathrm{L} \mathrm{Cd}+1.0 \mu \mathrm{g} / \mathrm{L} \mathrm{CBZ}$ compared to the control group, but was lower than the single-exposed Cd $(0.5 \mu \mathrm{g} / \mathrm{L})$ and CBZ (1.0 $\mu \mathrm{g} / \mathrm{L})$ groups, respectively [35]. In that research, no further combination concentrations were investigated. Some other studies investigated the effects induced by the coexposure of $\mathrm{Cd}$ and organic pollutants including PPCPs, showing that $\mathrm{Cd}$ effects on the aquatic organisms may depend on the type of organic pollutants present in aquatic systems $[34,37,40]$. 
CAT activity was reduced by Cd exposure, which may be because it was consumed by the degradation of the hydrogen peroxide produced during the superoxide disproportionation under oxidative stress [39,41]. CAT activity in mice also had similar tendencies after Cd exposure for seven days [42]. CAT activity was suppressed in the CBZ exposure group at a low concentration, but was induced in the group at high concentration. The data from the combined treatments suggests that the combined exposure of $\mathrm{Cd}$ and CBZ exerted weaker effects on CAT activity compared to single Cd exposure, indicating that the presence of the CBZ attenuated the Cd effects.

As previously mentioned, the combined effects of Cd with CBZ in zebrafish have not been studied. However, some researchers evaluated the effects of PPCPs combined with $\mathrm{Cd}$ or other metals in bivalves. For example, Almeida et al. observed that weaker effects on CAT activity in R. philippinarum were exerted by combined exposure of $0.5 \mu \mathrm{g} / \mathrm{L} \mathrm{Cd}+1.0 \mu \mathrm{g} / \mathrm{L} \mathrm{CBZ}$ than by single exposure of $0.5 \mu \mathrm{g} / \mathrm{L} \mathrm{Cd}$ [35]. Gonzalez-Rey et al. observed that Cu combined with PPCPs (ibuprofen, diclofenac, and fluoxetine) exerted weaker effects on CAT activity in mussel gills than single exposure by PPCPs [26].

AChE is a good candidate that is responsible for the hydrolysis of the neurotransmitter acetylcholine, which plays an important role in the nervous system [43]. AChE could be a target for pollutants, resulting in the inhibition of its activity, failure of synaptic transmission, and muscle overstimulation $[44,45]$. Thus, $\mathrm{AChE}$ activity has been used as a biomarker to evaluate the neurotoxicity of pollutants. Pan et al. studied the AChE activity in zebrafish gill, suggesting that $\mathrm{Cd}$ can inhibit the AChE activity in zebrafish: the higher the Cd concentration; the higher the inhibition degree of AChE activity [46]. This result was similar to the behavior response based on behavior strength, suggesting that inhibition exerted by $\mathrm{Cd}$ can induce a decrease of swimming behavior, loss of coordination, and other kinds of behavior change of zebrafish [47]. Juhel et al. observed that exposure to CBZ led to a significant reduction of AChE activity in Perna viridis [21]. Santos et al. observed that exposure to $10 \mu \mathrm{g} / \mathrm{L}$ CBZ led to slight reduction of AChE activity in zebrafish [47].

Interestingly, the present study showed that AChE activity in zebrafish was enhanced when exposed to combined stress of Cd and CBZ. The increase of AChE activity has been related to the production of free radicals [48] and to the apoptotic processes occurring in the organism $[49,50]$. AChE activity increase leads to fast acetylcholine degradation and downregulation of acetylcholine receptors, influencing the cognitive functions of the organism [51].

Metabolic regulation plays a very important role in environmental stress tolerance, since supplying enough energy to meet the energy demand is crucial for survival [52]. To assess the alterations in the pathways of cellular energy production induced by toxicants, LDH was quite often used, since it is the terminal enzyme of anaerobic glycolysis located in the cytoplasm [53]. Some previous studies showed that heavy metals can influence the LDH activity. For example, Pandy et al. found that mercury exposure can reduce the LDH activity in gill of L. marginailis [54]. Akintunde et al. found that LDH activity in rat can be reduced by mixed-metal exposure, including $\mathrm{Pd}, \mathrm{Cd}, \mathrm{Co}$, and $\mathrm{Cr}$ [55].

In the present study, we found that exposure to Cd can deplete LDH activity, which potentially indicates the increase of energy costs associated with raised metabolic regulatory demands [56]. $\mathrm{LDH}$ activity was induced by CBZ exposure and the combined exposure of CBZ and Cd, suggesting that increased use of the anaerobic pathways for producing energy is likely to require additional energy to deal with this stress factor. The increase in use of this pathway under pollution stress has been observed in several organisms exposed to contaminants [57-59].

VTG is an egg yolk precursor that is normally produced in oviparous females, which provides energy for embryonic development in adult female ovipara [60]. VTG has been considered as a sensitive biomarker for monitoring estrogenic activity in the environment [61], since it responds to estrogens circulating in blood plasma [60-62].

In the present study, VTG content and E2 decreased sharply in Cd exposure groups. For the case of VTG, since Cd has a strong affinity with estrogen receptor [63], we hypothesize that the binding of $\mathrm{Cd}$ with this receptor might reduce the available binding sites for estradiol, resulting in the reduction 
of VTG content. This hypothesis needs further experimentation to verify. For the case of E2, Cd is likely to completely abolish the E2 induction of the receptor gene and the estrogen receptors [64].

CBZ inhibited the VTG content and E2 in female zebrafish gradually. Some previous studies showed that CBZ has the potential to disrupt the endocrine system. For example, Aguirre-Martínez et al. found that VTG expression was reduced after 21 days of exposure to CBZ [65]. Hammill et al. found that parent exposure to CBZ can disrupt the sexual differentiation in the F1 offspring [66]. The reduction of VTG content in female fish is presumably due to the decrease in E2 [67], which agrees with the results in the present study (Figure 4A). Interestingly, the VTG and E2 content in female fish were also reduced by the combined exposure of $\mathrm{Cd}+\mathrm{CBZ}$, but are lower than those in the CBZ single exposure group. The detailed mechanism needs further research.

\section{Conclusions}

The present study implies that the combination of CBZ and Cd exerted different responses from those of the contaminants alone in female zebrafish. Exposure to environmentally relevant concentrations of $\mathrm{CBZ}, \mathrm{Cd}$, and their mixture can alter enzymes involved in the antioxidant system, energy metabolism, nervous system, and endocrine system disruption. This study could help gain a broad view on the risk assessment of these two pollutants, and highlights the need for a better understanding of the coeffects of environmental PPCPs and heavy metals on nontarget organisms. Measuring biomarkers is a common and efficient way to illustrate the toxic effect of pollutant exposure. To further verify these effects, other evidence, such as transcriptomics, proteomics, and histopathology, could be used in future studies.

Author Contributions: Experiment design and funding acquisition, C.S.; conceptualization, Y.H.; methodology, Y.H.; investigation and software, J.L.; formal analysis and validation, Y.L. (Yue Lu), Y.F. and Y.L. (Yaling Liang); writing—original draft preparation, Y.H.; writing—review and editing, Y.X.; supervision, Y.X.; project administration, Y.X.; funding acquisition, Y.X.

Funding: This research was funded by Natural Science Foundation of Jiangsu Province (No. BK20160989), National Key R\&D Program of China (2017YFB0602500), Jiangsu Innovative and Entrepreneurial Doctor Program and Nanjing Science and Technology Innovation Project for the Returned Overseas Scholars.

Conflicts of Interest: The authors declare no conflict of interest.

\section{References}

1. Heberer, T. Occurrence, fate, and removal of pharmaceutical residues in the aquatic environment: A review of recent research data. Toxicol. Lett. 2002, 131, 5-17. [CrossRef]

2. Collado, N.; Rodriguez-Mozaz, S.; Gros, M.; Rubirola, A.; Barcelo, D.; Comas, J.; Rodriguez-Roda, I.; Buttiglieri, G. Pharmaceuticals occurrence in a WWTP with significant industrial contribution and its input into the river system. Env. Pollut. 2014, 185, 202-212. [CrossRef] [PubMed]

3. Verlicchi, P.; Zambello, E. Pharmaceuticals and personal care products in untreated and treated sewage sludge: Occurrence and environmental risk in the case of application on soil - A critical review. Sci. Total Environ. 2015, 538, 750-767. [CrossRef] [PubMed]

4. Zenker, A.; Cicero, M.R.; Prestinaci, F.; Bottoni, P.; Carere, M. Bioaccumulation and biomagnification potential of pharmaceuticals with a focus to the aquatic environment. J. Environ. Manag. 2014, 133, 378-387. [CrossRef] [PubMed]

5. Boxall, A.B.; Rudd, M.A.; Brooks, B.W.; Caldwell, D.J.; Choi, K.; Hickmann, S.; Innes, E.; Ostapyk, K.; Staveley, J.P.; Verslycke, T.; et al. Pharmaceuticals and personal care products in the environment: what are the big questions? Environ. Health Perspect. 2012, 120, 1221-1229. [CrossRef]

6. Vernouillet, G.; Eullaffroy, P.; Lajeunesse, A.; Blaise, C.; Gagne, F.; Juneau, P. Toxic effects and bioaccumulation of carbamazepine evaluated by biomarkers measured in organisms of different trophic levels. Chemosphere 2010, 80, 1062-1068. [CrossRef]

7. Rogawski, M.A. Molecular targets versus models for new antiepileptic drug discovery. Epilepsy Res. 2006, 68, 22-28. [CrossRef] 
8. Zhang, Y.J.; Geissen, S.U.; Gal, C. Carbamazepine and diclofenac: Removal in wastewater treatment plants and occurrence in water bodies. Chemosphere 2008, 73, 1151-1161. [CrossRef]

9. Martinez, C.; Canle, M.; Fernandez, M.I.; Santaballa, J.A.; Faria, J. Kinetics and mechanism of aqueous degradation of carbamazepine by heterogeneous photocatalysis using nanocrystalline $\mathrm{TiO} 2, \mathrm{ZnO}$ and multi-walled carbon nanotubes-anatase composites. Appl. Catal. B-Environ. 2011, 102, 563-571. [CrossRef]

10. Doll, T.E.; Frimmel, F.H. Removal of selected persistent organic pollutants by heterogeneous photocatalysis in water. Catal. Today 2005, 101, 195-202. [CrossRef]

11. Caracciolo, A.B.; Topp, E.; Grenni, P. Pharmaceuticals in the environment: Biodegradation and effects on natural microbial communities. A review. J. Pharm. Biomed. 2015, 106, 25-36. [CrossRef] [PubMed]

12. Bahlmann, A.; Carvalho, J.J.; Weller, M.G.; Panne, U.; Schneider, R.J. Immunoassays as high-throughput tools: Monitoring spatial and temporal variations of carbamazepine, caffeine and cetirizine in surface and wastewaters. Chemosphere 2012, 89, 1278-1286. [CrossRef] [PubMed]

13. Calisto, V.; Bahlmann, A.; Schneider, R.J.; Esteves, V.I. Application of an ELISA to the quantification of carbamazepine in ground, surface and wastewaters and validation with LC-MS/MS. Chemosphere 2011, 84, 1708-1715. [CrossRef]

14. Martinez Bueno, M.J.; Boillot, C.; Fenet, H.; Chiron, S.; Casellas, C.; Gomez, E. Fast and easy extraction combined with high resolution-mass spectrometry for residue analysis of two anticonvulsants and their transformation products in marine mussels. J. Chromatogr. A 2013, 1305, 27-34. [CrossRef]

15. Puckowski, A.; Mioduszewska, K.; Lukaszewicz, P.; Borecka, M.; Caban, M.; Maszkowska, J.; Stepnowski, P. Bioaccumulation and analytics of pharmaceutical residues in the environment: A review. J. Pharm. Biomed. Anal. 2016, 127, 232-255. [CrossRef]

16. Aguirre-Martinez, G.V.; DelValls, T.A.; Martin-Diaz, M.L. General stress, detoxification pathways, neurotoxicity and genotoxicity evaluated in Ruditapes philippinarum exposed to human pharmaceuticals. Ecotox. Environ. Saf. 2016, 124, 18-31. [CrossRef]

17. Almeida, A.; Calisto, V.; Esteves, V.I.; Schneider, R.J.; Soares, A.M.V.M.; Figueira, E.; Freitas, R. Toxicity associated to uptake and depuration of carbamazepine in the clam Scrobicularia plana under a chronic exposure. Sci. Total Environ. 2017, 580, 1129-1145. [CrossRef]

18. Juhel, G.; Bayen, S.; Goh, C.; Lee, W.K.; Kelly, B.C. Use of a suite of biomarkers to assess the effects of carbamazepine, bisphenol A, atrazine, and their mixtures on green mussels, Perna viridis. Environ. Toxicol. Chem. 2017, 36, 429-441. [CrossRef]

19. Dietrich, S.; Ploessl, F.; Bracher, F.; Laforsch, C. Single and combined toxicity of pharmaceuticals at environmentally relevant concentrations in Daphnia magna-a multigenerational study. Chemosphere 2010, 79, 60-66. [CrossRef]

20. Ramakrishnan, L.; Desaer, C. Carbamazepine inhibits distinct chemoconvulsant-induced seizure-like activity in Dugesia tigrina. Pharm. Biochem. Behav. 2011, 99, 665-670. [CrossRef] [PubMed]

21. Yan, S.H.; Wang, M.; Zha, J.M.; Zhu, L.F.; Li, W.; Luo, Q.; Sun, J.; Wang, Z.J. Environmentally Relevant Concentrations of Carbamazepine Caused Endocrine-Disrupting Effects on Nontarget Organisms, Chinese Rare Minnows (Gobiocypris rarus). Environ. Sci. Technol. 2018, 52, 886-894. [CrossRef]

22. Bound, J.P.; Voulvoulis, N. Pharmaceuticals in the aquatic environment - a comparison of risk assessment strategies. Chemosphere 2004, 56, 1143-1155. [CrossRef]

23. Gonzalez-Rey, M.; Mattos, J.J.; Piazza, C.E.; Bainy, A.C.D.; Bebianno, M.J. Effects of active pharmaceutical ingredients mixtures in mussel Mytilus galloprovincialis. Aquat. Toxicol. 2014, 153, 12-26. [CrossRef]

24. Andreu, V.; Gimeno-Garcia, E.; Pascual, J.A.; Vazquez-Roig, P.; Pico, Y. Presence of pharmaceuticals and heavy metals in the waters of a Mediterranean coastal wetland: Potential interactions and the influence of the environment. Sci. Total Environ. 2016, 540, 278-286. [CrossRef] [PubMed]

25. Martins, V.V.; Zanetti, M.O.; Pitondo-Silva, A.; Stehling, E.G. Aquatic environments polluted with antibiotics and heavy metals: a human health hazard. Environ. Sci. Pollut. Rsc. Int. 2014, 21, 5873-5878. [CrossRef] [PubMed]

26. Damasio, J.; Barcelo, D.; Brix, R.; Postigo, C.; Gros, M.; Petrovic, M.; Sabater, S.; Guasch, H.; de Alda, M.L.; Barata, C. Are pharmaceuticals more harmful than other pollutants to aquatic invertebrate species: A hypothesis tested using multi-biomarker and multi-species responses in field collected and transplanted organisms. Chemosphere 2011, 85, 1548-1554. [CrossRef] 
27. Wu, C.; Zhang, Y.H.; Chai, L.H.; Wang, H.Y. Oxidative stress, endocrine disruption, and malformation of Bufo gargarizans embryo exposed to sub-lethal cadmium concentrations. Environ. Toxicol. Phar. 2017, 49, 97-104. [CrossRef]

28. Achary, K.K.; Satpathy, S.; Panigrahi, A.K.; Mohanty, R.K.; Padhi, S.; Biswas, R.K.; Prabhu, S.; Vijayalakshmi, R.C. Panigrahy, Concentration of heavy metals in the food chain components of the nearshore coastal waters of Kalpakkam, southeast coast of India. Food Control 2017, 72, 232-243. [CrossRef]

29. Jitar, O.; Teodosiu, C.; Oros, A.; Plavan, G.; Nicoara, M. Bioaccumulation of heavy metals in marine organisms from the Romanian sector of the Black Sea. New Biotechnol. 2015, 32, 369-378. [CrossRef]

30. Yiğiterhan, O.; Murray, J.W.; Tuğrul, S. Trace metal composition of suspended particulate matter in the water column of the Black Sea. Mar. Chem. 2011, 126, 207-228.

31. Geret, F.; Serafim, A.; Barreira, L.; Bebianno, M.J. Effect of cadmium on antioxidant enzyme activities and lipid peroxidation in the gills of the clam Ruditapes decussatus. Biomarkers 2002, 7, 242-256. [CrossRef] [PubMed]

32. Jo, P.G.; Choi, Y.K.; Choi, C.Y. Cloning and mRNA expression of antioxidant enzymes in the Pacific oyster, Crassostrea gigas in response to cadmium exposure. Comp. Biochem. Physiol. C Toxicol. Pharmacol. 2008, 147, 460-469. [CrossRef] [PubMed]

33. Figueira, E.; Cardoso, P.; Freitas, R. Ruditapes decussatus and Ruditapes philippinarum exposed to cadmium: toxicological effects and bioaccumulation patterns. Comp. Biochem. Physiol. C Toxicol. Pharmacol. 2012, 156, 80-86. [CrossRef]

34. Ragusa, M.A.; Costa, S.; Cuttitta, A.; Gianguzza, F.; Nicosia, A. Coexposure to sulfamethoxazole and cadmium impairs development and attenuates transcriptional response in sea urchin embryo. Chemosphere 2017, 180, 275-284. [CrossRef] [PubMed]

35. Almeida, A.; Calisto, V.; Esteves, V.I.; Schneider, R.J.; Soares, A.; Figueira, E.; Freitas, R. Effects of single and combined exposure of pharmaceutical drugs (carbamazepine and cetirizine) and a metal (cadmium) on the biochemical responses of R. philippinarum. Aquat. Toxicol. 2018, 198, 10-19. [CrossRef] [PubMed]

36. Li, Z.H.; Li, P.; Randak, T. Protective roles of calcium channel blocker against cadmium-induced physiological stress in freshwater teleost oncorhynchus mykiss. Water Air Soil Pollut. 2011, 220, 293-299. [CrossRef]

37. Almeida, A.; Calisto, V.; Domingues, M.R.M.; Esteves, V.I.; Schneider, R.J.; Soares, A.M.V.M.; Figueira, E.; Freitas, R. Comparison of the toxicological impacts of carbamazepine and a mixture of its photodegradation products in Scrobicularia plana. J. Hazard. Mater. 2017, 323, 220-232. [CrossRef]

38. Yin, J.; Wang, A.P.; Li, W.F.; Shi, R.; Jin, H.T.; Wei, J.F. Time-response characteristic and potential biomarker identification of heavy metal induced toxicity in zebrafish. Fish Shellfish Immunol. 2018, 72, 309-317. [CrossRef]

39. Li, Z.H.; Zlabek, V.; Velisek, J.; Grabic, R.; Machova, J.; Randak, T. Modulation of antioxidant defence system in brain of rainbow trout (Oncorhynchus mykiss) after chronic carbamazepine treatment. Comp. Biochem. Physiol. C Toxicol. Pharmacol. 2010, 151, 137-141. [CrossRef]

40. Wang, L.; Pan, L.Q.; Liu, N.; Liu, D.; Xu, C.Q.; Miao, J.J. Biomarkers and bioaccumulation of clam Ruditapes philippinarum in response to combined cadmium and benzo[alpha]pyrene exposure. Food Chem. Toxicol. 2011, 49, 3407-3417. [CrossRef]

41. Adeyemi, J.A.; da Cunha Martins-Junior, A.; Barbosa, F., Jr. Teratogenicity, genotoxicity and oxidative stress in zebrafish embryos (Danio rerio) co-exposed to arsenic and atrazine. Comp. Biochem. Physiol. C Toxicol. Pharmacol. 2015, 172-173, 7-12. [CrossRef]

42. Liu, L.; Tao, R.H.; Huang, J.; He, X.Z.; Qu, L.Y.; Jin, Y.X.; Zhang, S.B.; Fu, Z.W. Hepatic oxidative stress and inflammatory responses with cadmium exposure in male mice. Environ. Toxicol. Pharmacol. 2015, 39, $229-236$. [CrossRef] [PubMed]

43. Fukuto, T.R. Mechanism of action of organophosphorus and carbamate insecticides. Environ. Health Perspect. 1990, 87, 245-254. [CrossRef]

44. Schmidel, A.J.; Assmann, K.L.; Werlang, C.C.; Bertoncello, K.T.; Francescon, F.; Rambo, C.L.; Beltrame, G.M.; Calegari, D.; Batista, C.B.; Blaser, R.E.; et al. Subchronic atrazine exposure changes defensive behaviour profile and disrupts brain acetylcholinesterase activity of zebrafish. Neurotoxicol. Teratol. 2014, 44, 62-69. [CrossRef] 
45. Topal, A.; Alak, G.; Ozkaraca, M.; Yeltekin, A.C.; Comakli, S.; Acil, G.; Kokturk, M.; Atamanalp, M. Neurotoxic responses in brain tissues of rainbow trout exposed to imidacloprid pesticide: Assessment of 8-hydroxy-2-deoxyguanosine activity, oxidative stress and acetylcholinesterase activity. Chemosphere 2017, 175, 186-191. [CrossRef] [PubMed]

46. Pan, H.W.; Zhang, X.; Ren, B.X.; Yang, H.H.; Ren, Z.M.; Wang, W.L. Toxic assessment of cadmium based on online swimming behavior and the continuous AChE activity in the gill of Zebrafish (Danio rerio). Water Air Soil Pollut. 2017, 228, 355. [CrossRef]

47. da Silva Santos, N.; Oliveira, R.; Lisboa, C.A.; Mona, E.P.J.; Sousa-Moura, D.; Camargo, N.S.; Perillo, V.; Oliveira, M.; Grisolia, C.K.; Domingues, I. Chronic effects of carbamazepine on zebrafish: Behavioral, reproductive and biochemical endpoints. Ecotoxicol. Environ. Saf. 2018, 164, 297-304. [CrossRef] [PubMed]

48. Ferreira, G.K.; Carvalho-Silva, M.; Goncalves, C.L.; Vieira, J.S.; Scaini, G.; Ghedim, F.V.; Deroza, P.F.; Zugno, A.I.; Pereira, T.C.B.; Oliveira, G.M.T.; et al. L-Tyrosine administration increases acetylcholinesterase activity in rats. Neurochem. Int. 2012, 61, 1370-1374. [CrossRef] [PubMed]

49. Zhang, X.J.; Yang, L.; Zhao, Q.; Caen, J.P.; He, H.Y.; Jin, Q.H.; Guo, L.H.; Alemany, M.; Zhang, L.Y.; Shi, Y.F. Induction of acetylcholinesterase expression during apoptosis in various cell types. Cell Death Differ. 2002, 9, 790-800. [CrossRef]

50. Zhang, B.; Yang, L.; Yu, L.Y.; Lin, B.; Hou, Y.N.; Wu, J.; Huang, Q.; Han, Y.F.; Guo, L.H.; Ouyang, Q.; Zhang, B.; Lu, L.; Zhang, X.J. Acetylcholinesterase is associated with apoptosis in cells and contributes to insulin-dependent diabetes mellitus pathogenesis. Acta Biochim. Biophys. Sin. (Shanghai) 2012, 44, 207-216. [CrossRef] [PubMed]

51. Tougu, V.; Kesvatera, T. Role of ionic interactions in cholinesterase catalysis. Biochim. Biophys. Acta 1996, 1298, 12-30. [CrossRef]

52. Dorts, J.; Kestemont, P.; Thezenas, M.L.; Raes, M.; Silvestre, F. Effects of cadmium exposure on the gill proteome of Cottus gobio: Modulatory effects of prior thermal acclimation. Aquat. Toxicol. 2014, 154, 87-96. [CrossRef]

53. Vieira, L.R.; Sousa, A.; Frasco, M.F.; Lima, I.; Morgado, F.; Guilhermino, L. Acute effects of Benzo[a]pyrene, anthracene and a fuel oil on biomarkers of the common goby Pomatoschistus microps (Teleostei, Gobiidae). Sci. Total Environ. 2008, 395, 87-100. [CrossRef]

54. Pandey, A.; Singh, A.; Holeyappa, S.A.; Kaur, H. Enzymatic and antioxidant response of Lamellidens marginalis exposed to mercuric chloride. Indian J. Animal Res. 2018, 52, 658-663. [CrossRef]

55. Akintunde, J.K.; Oboh, G.; Akindahunsi, A.A. Inhibition of key markers linked with spermatogenesis and cellular ATP by subchronic exposure to leachate in a rat model. Arch. Environ. Contam. Toxicol. 2015, 68, 159-168. [CrossRef]

56. Adham, K.G.; Al-Eisa, N.A.; Farhood, M.H. Impact of heavy metal pollution on the hemogram and serum biochemistry of the libyan jird, Meriones libycus. Chemosphere 2011, 84, 1408-1415. [CrossRef] [PubMed]

57. Firat, O.; Cogun, H.Y.; Yuzereroglu, T.A.; Gok, G.; Firat, O.; Kargin, F.; Kotemen, Y. A comparative study on the effects of a pesticide (cypermethrin) and two metals (copper, lead) to serum biochemistry of Nile tilapia, Oreochromis niloticus. Fish Physiol. Biochem. 2011, 37, 657-666. [CrossRef] [PubMed]

58. Oliveira, C.; Almeida, J.; Guilhermino, L.; Soares, A.M.V.M.; Gravato, C. Acute effects of deltamethrin on swimming velocity and biomarkers of the common prawn Palaemon serratus. Aquat. Toxicol. 2012, 124, 209-216. [CrossRef]

59. Vieira, L.R.; Gravato, C.; Soares, A.M.V.M.; Morgado, F.; Guilhermino, L. Acute effects of copper and mercury on the estuarine fish Pomatoschistus microps: Linking biomarkers to behaviour. Chemosphere 2009, 76, 1416-1427. [CrossRef]

60. Arukwe, A.; Goksoyr, A. Eggshell and egg yolk proteins in fish: hepatic proteins for the next generation: oogenetic, population, and evolutionary implications of endocrine disruption. Comp. Hepatol. 2003, 2, 4. [CrossRef] [PubMed]

61. Filby, A.L.; Santos, E.M.; Thorpe, K.L.; Maack, G.; Tyler, C.R. Gene expression profiling for understanding chemical causation of biological effects for complex mixtures: A case study on Estrogens. Environ. Sci. Technol. 2007, 41, 8187-8194. [CrossRef] [PubMed]

62. Sole, M.; Porte, C.; Barcelo, D. Analysis of the estrogenic activity of sewage treatment works and receiving waters using vitellogenin induction in fish as a biomarker. TrAC Trends Anal. Chem. 2001, 20, 518-525. [CrossRef] 
63. Stoica, A.; Katzenellenbogen, B.S.; Martin, M.B. Activation of estrogen receptor-alpha by the heavy metal cadmium. Mol. Endocrinol. 2000, 14, 545-553.

64. Chouchene, L.; Pellegrini, E.; Gueguen, M.M.; Hinfray, N.; Brion, F.; Piccini, B.; Kah, O.; Said, K.; Messaoudi, I.; Pakdel, F. Inhibitory effect of cadmium on estrogen signaling in zebrafish brain and protection by zinc. J. Appl. Toxicol. 2016, 36, 863-871. [CrossRef]

65. Aguirre-Martinez, G.V.; Andre, C.; Gagne, F.; Martin-Diaz, L.M. The effects of human drugs in Corbicula fluminea. Assessment of neurotoxicity, inflammation, gametogenic activity, and energy status. Ecotoxicol. Environ. Saf. 2018, 148, 652-663. [CrossRef] [PubMed]

66. Hammill, K.M.; Fraz, S.; Lee, A.H.; Wilson, J.Y. The effects of parental carbamazepine and gemfibrozil exposure on sexual differentiation in zebrafish (Danio rerio). Environ. Toxicol. Chem. 2018, 37, 1696-1706. [CrossRef]

67. Girish, B.P.; Swetha, C.H.; Reddy, P.S. Hepatopancreas but not ovary is the site of vitellogenin synthesis in female fresh water crab, Oziothelphusa senex senex. Biochem. Biophys. Res. Commun. 2014, 447, 323-327. [CrossRef] [PubMed]

(C) 2019 by the authors. Licensee MDPI, Basel, Switzerland. This article is an open access article distributed under the terms and conditions of the Creative Commons Attribution (CC BY) license (http:/ / creativecommons.org/licenses/by/4.0/). 